\title{
DOEE/ET/22935--7/
}

\section{MAINTAINING THE URANIUM RESOURCES DATA SYSTEM AND ASSESSING THE 1991 U.S. URANIUM POTENTIAL RESOURCES}

DOE/EI/22935--Ti

\section{Final Report}

December 31, 1992

By

R.B. McCammon, ${ }^{*}$ W.I. Finch, ${ }^{* *}$ W.D. Grundy, ${ }^{* *}$ and C.T. Pierson ${ }^{* *}$

U.S. Geological Survey

Reston, Virginia* and Denver, Colorado**

Partial fulfillment of Contract Under Interagency Agreement

DE-AI01-92EI22935

U.S. Department of Energy

Energy Information Administration

Washington, D.C.

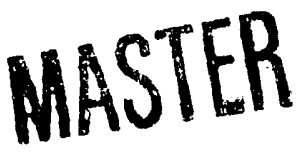




\section{TABLE OF CONTENTS}

PAGE

Executive Summary

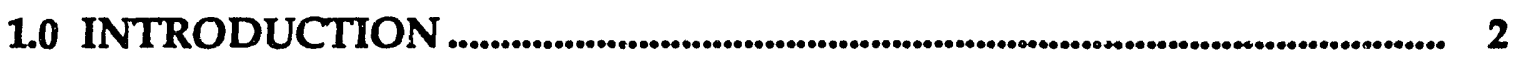

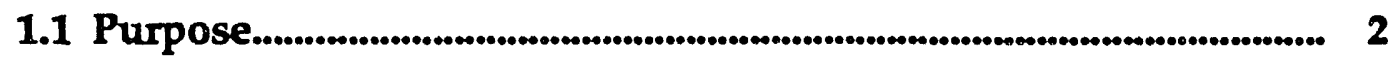

1.2 Background on the URAD System.................................................... 2

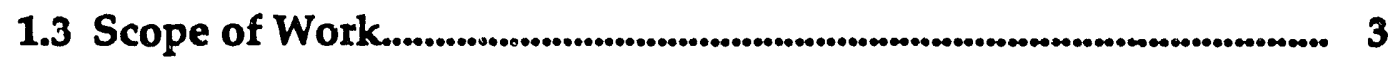

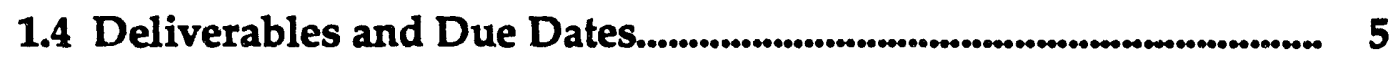

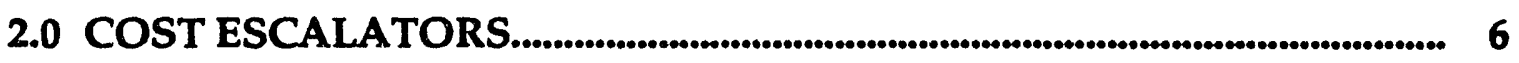

2.1 Updated 1991 Economic Indicators................................................................. 6

2.2 Cost Factor Generator (CFG) ......................................................... 7

3.01991 URANIUM RESOURCE ESTIMATES ........................................ 7

3.1 Support from the U.S. Geological Survey............................................. 7

3.2 Uranium Endowment by Resource Region............................................. 8

3.3 Estimated Additional Resources (EAR) and Speculative

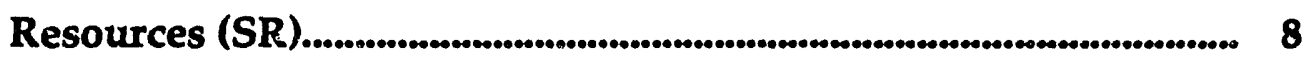

3.4 Distribution of EAR and SR by Resource Region............................ 10

3.5 Distribution of EAR and SR by Land Status............................................... 11

4.0 ADJUSTMENT TO GRADE CUP-OFF THRESHOLD VALUE ................. 19

4.1 Resource Estimates for Obtained Using the Grade Cut-off Threshold Value of 1.00 Percent $\mathrm{U}_{3} \mathrm{O}_{8} \ldots \ldots$

5.0 RUNNING THE URAD SYSTEM ON USGS COMPUTERS ...................... 24

5.1 Improvements and Additions to the URAD System ....................... 24

5.2 Debugging FORTRAN Source Code of URAD Programs.............. 24

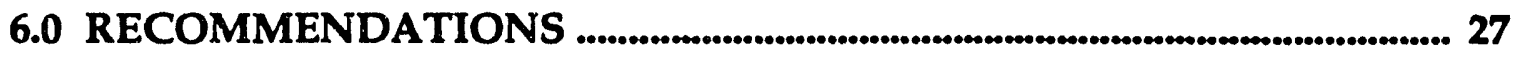

6.1 Proposal for Update of Mining and Milling Cost Models.............. 27 
6.2 State Tax Equations....................................................................................... 28

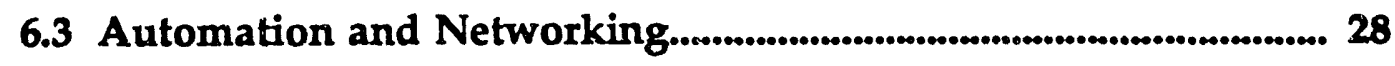

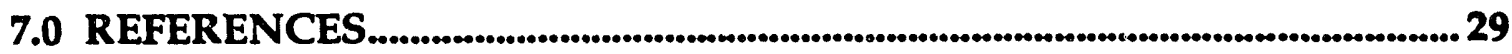

\section{TABLES}

Table 1. Uranium Endowment by Resource Region at the End of 1991 .... 12

Table 2. Estimated Additional Resources (EAR) and Speculative Resources (SR) at the End of the Year, 1974-1991...................................... 13

Table 3. Estimated Additional Resources (EAR) and Speculative Resources (SR) by Resource Region at the End of 1991 .................... 14

Table 4. Estimated Additional Resources (EAR) and Speculative Resources (SR) in the \$50-per Pound Forward-Cost Category

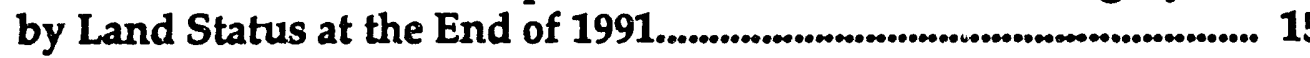

Table 5. Uranium Endowment by Resource Region at the End of 1991 .... 20

Table 6. Estimated Additional Resources (EAR) and Speculative Resources (SR) at the End of the Year, 1974-1991................................. 21

Table 7. Estimated Additional Resources (EAR) and Speculative Resources (SR) by Resource Region at the End of 1991.

Table 8. Estimated Additional Resources (EAR) and Speculative Resources (SR) in the \$50-per Pound Forward-Cost Category by Land Status at the End of 1991. 


\section{FIGURES}

Figure 1. Uranium resource regions of the United States............................. 16

Figure 2. Trends of the economic indexes Wholesale Price IndexIndustrial Commodities (WPI), the Marshall and Swift Mining-Milling Equipment Cost Index (MSI), and the Chemical Engineering Plant Cost Index (CEP) and of the average annual $\mathrm{U}_{3} \mathrm{O}_{8}$ spot market prices as determined by the average of NUEXCO monthly exchange prices from 1980-1991.. 17

Figure 3. Distribution of $\$ 50$-pound $\mathrm{U}_{3} \mathrm{O}_{8} \mathrm{EAR}$ by region............................. 18

Figure 4. Probability plot of U.S. potential uranium resources....................... 26 


\section{EXECUTIVE SUMMARY}

Under the Memorandum of Understanding (MOU) between the EIA, U.S. Department of Energy, and the U.S. Geological Survey (USGS), U.S. Department of the Interior, the USGS develops estimates of uranium endowment for selected geological environments in the United States. New estimates of endowment are

used to update the Uranium Resources Assessment Data (URAD) System which, beginning in 1990, is maintained for EIA by the USGS.

For 1991, estimates of U.S. undiscovered resources were generated using revised economic index values (current to December 1991) in the URAD system's cost model. The higher 1991 indexes which resulted in increased costs were offset by the removal of the cut-off grade threshold value used in the URAD system's cost model and, together with the new assessment of the Flodelle Creek area in Washington, resulted in slightly higher estimates of the quantities of EAR and SR for 1991 for most regions when compared to 1990. The endowments associated with the EAR values for all regions are unchanged from the 1990 values. The endowments associated with the SR values for all regions except for the Northern Rockies are unchanged from the 1990 values. For the Northern Rockies, the SR value increased to 3,940 million pounds $\mathrm{U}_{3} \mathrm{O}_{8}$ from 3,860 million pounds in 1990 . For 1991 , the mean values for the $\$ 30-, \$ 50$-, and $\$ 100$-per pound $\mathrm{U}_{3} \mathrm{O}_{8}$ forward-cost EAR category resources show no change when compared to the values in 1990 . The mean values for the $\$ 30-, \$ 50$-, and $\$ 100$-per pound $\mathrm{U}_{3} \mathrm{O}_{8}$ forward-cost $\mathrm{SR}$ forwardcost category show increases of 8,5 , and 3 percent, respectively.

Improvements to the URAD system included automating the procedures necessary to generate the assessment reports. Data retrieval from the URAD system can now be performed using the dBase IV version 1.5 data base management system. The conversion to dBase IV was made because this system is more widely used and 
more flexible than the earlier system, $\mathrm{dBXL}$, and is somewhat faster. Additions to the URAD system include the capability of generating graphs of the EAR, SR, and the endowment, respectively.

\section{$1.0 \quad$ INTRODUCTION}

\subsection{Purpose}

The purpose of this report is: (1) to describe the work carried out to maintain and update the Uranium Resource Assessment Data (URAD) System, (2) to assess the 1991 U.S. uranium potential resources in various cost categories, and (3) to describe the progress that has been made to autumate the generation of the assessment reports and their subsequent transmittal by diskette.

\subsection{Background on the URAD System}

The Energy Information Administration's (EIA) Uranium Resource Assessment Data System contains information on potential resources (undiscovered) of uranium in the United States. The unique mathematical procedures in this system were developed prior to 1983 by Oak Ridge National Laboratory (ORNL) personnel, principally Mr. C.E. Ford and Dr. A.R. McLaren, under the sponsorship of the Grand Junction Area Office of the U.S. Department of Energy (Ford and McLaren, 1980). The URAD System was developed originally on a DEC-101 computer. During 1989-1990, the System was converted to operate on IBMcompatible microcomputers by personnel of the Resource Modeling and Technology Economics Group, Energy Division, ORNL, principally Dr. G.L. Chen and Mr. Sujit Das, and by subcontractors, Mr. R. Perubhatla and Mr. R.A. Whitaker, from Coe College and University of Tennessee, respectively (Das and Lee, 1991; Chen and others, 1990; Das and others, 1988).

\footnotetext{
${ }^{1}$ Use of trade names in this report is for identification purposes only and does not imply endorsement by the U.S. Geological Survey.
} 
The URAD System is used to store subjective geological data on uranium resources for 706 resource areas in the United States. Probabilistic numerical procedures are utilized to compute estimates of resource quantities from these geological data. Estimates are produced for areas that have geological characteristics favorable for the occurrence of uranium deposits. The estimates are classified into categories of Estimated Additional Resources (EAR) and Speculative Resources (SR) and into Forward Cost Categories of $\$ 30, \$ 50$, and $\$ 100$ per pound $\mathrm{U}_{3} \mathrm{O}_{8}$. Although the URAD System is analytically detailed and rigorous, extensive checking, verification, and in some cases revising of URAD output by a knowledgeable geologist is required to assure the quality and reliability of the output data for publication.

Under a Memorandum of Understanding (MOU) between the EIA, U.S. Department of Energy, and the U.S. Geological Survey (USGS), U.S. Department of the Interior, the USGS develops estimates of uranium endowment for selected geological environments in the United States (Finch and McCammon, 1987). The new endowment data are used to update the URAD System files.

Tabulations of U.S. potential resources data are used in the EIA publication Uranium Industry Annual (UIA) and in the EIA's submission for the biennial report Uranium Resources, Production, and Demand, which is published jointly by the Organization for Economic Co-operation and Development (OECD) Nuclear Energy Agency and the International Atomic Energy Agency. The data are also used in preparing the EIA's annual report, Domestic Uranium Mining and Milling Industry, Viability Assessment.

\subsection{Scope of Work}

Under the terms of the present agreement, the USGS is responsible for work on the following Subtasks: 
Subtask 1: Cost Escalators - Update 1991 economic indicators for the Cost Factor Generator (CFG) in the URAD System. These indicators are:

a. The Department of Commerce's "Producer Price Index for Industrial Commodities."

b. The "Marshall and Swift Mining-Milling Equipment Cost Index."

c. The "Chemical Engineering Plant Cost Index."

d. The annual spot market price, or "MPRICE" for $\mathrm{U}_{3} \mathrm{O}_{8}$ concentrate; as determined by the average of Nuexco monthly exchange prices.

Subtask 2: URAD System Maintenance and Computations. This includes:

a. Manage and maintain the URAD System residing at the USGS computer facility.

b. Provide support in updating system parameters (i.e., reference information, cost-model data, master-file data, etc.) and the potential resources data in the URAD System as requested by the EIA.

c. Provide support in updating existing formulas in the Cost Factor Generator and/or adding new subroutines to describe current economic conditions brought about by changes in mining/processing technologies and tax laws.

d. Provide assistance when requested by the EIA in accessing and running the URAD System concerning uranium potential resources.

e. When requested, review and analyze new mathematical and statistical methods of resource estimation and other modifications that are being considered for use in updating the URAD System with state-of-the-art resource-estimation procedures. Provide the EIA with expert judgments and findings regarding the suitability of updating the URAD System to incorporate such new procedures. If this task should require a major effort, the contract may be amended to include reimbursable costs 
f. Provide results of URAD-computer potential uranium resources for 1991 from the following standard Tasks (reports); 3, 4, 10, 13, 14, 20, 21, 22, and 23 (Appendix I, "Description of Tasks Available" for description of reports). In addition to these Tasks (reports), a set of cumulative probability distribution graphs showing 1991 uranium resources data from the MAPPER files output also shall be provided by the contractor.

g. Compile final uranium Estimated Additional Resources (EAR) and Speculative Resources (SR) assessment for the \$30, $\$ 50$, and $\$ 100$ per pound $\mathrm{U}_{3} \mathrm{O}_{8}$ cost categories for 1991 . In addition, the contractor shall provide a narrative description in support of the assessments and to compare the results to the assessment from the previous year.

\subsection{Deliverables and Due Dates}

A. Description of Deliverables

\section{Due Dates}

1. Report on updated cost escalation indicators

April 30, 1992

2. Report of $1989 \mathrm{EAR}$ and $\mathrm{SR}$ for various cost categories

June 15, 1992

3. Draft Final Report

November 30, 1992

4. Final report on URAD System maintenance and 1989 potential resources assessment

December 31, 1992

B. Reports shall be submitted in accordance with the Reporting Requirements Checklist.

C. The agency shall also deliver one (1) reproducible master of the final technical report to the Office of Scientific and Technical Information at the following address:

Department of Energy

Office of Scientific and Technical Information (OSTI)

Special Assistant for Reproduction and Processing

Post Office Box 62

Oak Ridge, Tennessee 37830 


\subsection{COST ESCALATORS}

\subsection{Updated 1991 Economic Indicators}

Under Subtask 1 of the Scope of Work outlined in Section 1.3, the 1991 updated cost escalation indices are as follows:

Economic Indicators

$\begin{array}{lrrr}\text { Yr. } & \text { WPI }^{2} & \text { CEP }^{3} & \text { M\&S }^{4} \\ 1980 & 88.0 & 261.2 & 659.6 \\ 1981 & 97.4 & 297.0 & 721.3 \\ 1982 & 100.0 & 314.0 & 745.6 \\ 1983 & 101.1 & 316.9 & 760.8 \\ 1984 & 103.3 & 322.7 & 780.4 \\ 1985 & 103.7 & 325.3 & 789.6 \\ 1986 & 100.0 & 318.4 & 797.6 \\ 1987 & 102.6 & 323.8 & 813.6 \\ 1988 & 106.3 & 342.5 & 852.0 \\ 1989 & 111.6 & 355.4 & 895.1 \\ 1990 & 115.8 & 357.6 & 915.1 \\ 1991 & 116.5 & 361.3 & 930.6\end{array}$

Cost Escalators updated 4/30/92

$$
\begin{aligned}
& \text { CEP80 }=361.3 / 251.2=1.3832312 \\
& \text { MSI80 }=930.6 / 659.6=1.4108551 \\
& \text { MSI82 }=930.6 / 745.6=1.2481223 \\
& \text { WPI80 }=116.5 / 88.0=1.3238636 \\
& \text { WPI81 }=116.5 / 97.4=1.1960986 \\
& \text { WPI82 }=116.5 / 100.0=1.1650000
\end{aligned}
$$

Annual average spot market price for $\mathrm{U}_{3} \mathrm{O}_{8}$ concentrate based on exchange value determined as of the last day of the month ( $\$ \mathrm{US} / \mathrm{lb} \mathrm{U}_{3} \mathrm{O}_{8}$ ).

Yr. Avg. Price 5

$1991 \quad 8.78$

2Producer Price Index (Industrial Commodities), Bureau of Labor Statistics.

${ }^{3}$ Chemical Engineering Plant Cost Index, Chemical Engineering, April 1992.

${ }^{4}$ Marshall \& Swift Equipment Cost Index, Chemical Engineering, April, 1992.

${ }^{5}$ Nuexco Historical Market Data, April, 1992. 


\subsection{Cost Factor Generator (CFG)}

The updated cost escalators are used to generate components of capital and operating costs in the Cost Factor Generator, Version 102 Subroutine in the URAD System. The values are stored in a file named "CFGPI."

\subsection{URANIUM RESOURCE ESTIMATES}

Using the URAD data records and the PC-based dBXL database management system, the updated 1991 economic indicators discussed in Section 2.1 were entered, and the 1991 EAR and SR for the various cost categories were submitted to EIA on June 15, 1992. The following sections are slightly modified after those published in the Uranium Industry Annual 1991 (EIA, 1992).

\subsection{Support from the U.S. Geological Survey}

In accordance with a Memorandum of Understanding (MOU) signed in 1984 between the EIA and the U.S. Geological Survey (USGS) of the U.S. Department of the Interior, the USGS provides to the EIA annual estimates of the Nation's uranium endowment. Uranium endowment is the quantity of uranium estimated to occur in rock with a grade of at least 0.01 percent $\mathrm{U}_{3} \mathrm{O}_{8}$. Through its ongoing geological programs, the USGS conducts studies of uranium districts and favorable geological environments in selected localities where, because of the availability of new scientific knowledge or industry-developed information relating to uranium resources, opportunities exist for updating the National uranium resource data base, the Uranium Resources Assessment Data (URAD). In this manner, the USGS is continuing the assessment of Nation's Uranium endowment begun the DOE's prior uranium resource appraisal program, National Uranium Resources Evaluation (NURE), which was phased out in 1983. The methodology used by the USGS to develop the U.S. uranium endowment estimates is a modification of the methodology developed during the NURE program by the DOE (Blanchfield, 1980; Finch and McCammon, 1987). 
The EIA uses the uranium endowment data to prepare annual estimates of U.S. potential uranium resources, which consist of the portions of the endowment, estimated for each favorable locality, that could be recoverable at selected forward costs of production, based on economic evaluation of anticipated operating and capital costs, cutoff grade, minimum mining grade, and other factors.

\subsection{Uranium Endowment by Resource Region}

Uranium endowment is the total quantity of estimated resources, irrespective of economic considerations, above 0.01 percent $\mathrm{U}_{3} \mathrm{O}_{8}$ within geographic areas that have geologic characteristics favorable for uranium deposits. Endowment includes the undiscovered resources (EAR and SR), which are derived by determining economically recoverable portions of the endowment at stipulated maximum forward costs of producing the uranium. distribution of the mean values of uranium endowment is shown by resource region in Table 1 (Figure 1). The endowments associated with the EAR values for all regions are unchanged from the 1990 values. The endowments associated with the SR values for all regions except for the Northern Rockies are unchanged from the 1990 values. For the Northern Rockies, the SR value increased to 3,940 million pounds $\mathrm{U}_{3} \mathrm{O}_{8}$ from 3,860 million pounds in 1990.

\subsection{Estimated Additional Resources (EAR) and Speculative Resources (SR)}

The estimates of EAR and SR presented in this section were developed from a data base of information on uranium deposits and mining economics compiled during the past three decades of Government and industry activities. The data base includes the extensive data on undiscovered uranium resources that were compiled during the NURE program as well as additional data provided by the U.S. Geological Survey. These data are maintained in the Uranium Resources Assessment Data (URAD) system, which is used to generate current estimates of undiscovered resources of uranium at the forward costs of $\$ 30-, \$ 50$-, and $\$ 100$-per-pound $\mathrm{U}_{3} \mathrm{O}_{8}$. 
For 1992, estimates of U.S. undiscovered resources were generated using revised economic index values (current to December 1991) in the URAD system's cost model. The economic indexes are the Witulesale Price Index-Industrial Commodities (WPI), the Marshali and Swift Mining-Milling Equipment Cost Index (MSI), and the Chemical Engineering Plant Cost Index (CEF'). The trends of these cost indexes and average annual $\mathrm{U}_{3} \mathrm{O}_{8}$ spot market prices from 1980 to 1991 are shown in Figure 2. The 1991 spot market price, or "MPRICE", for $\mathrm{U}_{3} \mathrm{O}_{8}$ concentrate as determined by the average of NUEXCO monthly exchange prices was $\$ 8.78$. In 1991, the URAD rost model was revised by raising the threshold value for the average-grade cutoff. This was done in order to more accurately reflect the higher rarige of average grades encountered in deposits in the breccia-pipe environment in northern Arizona. Revised EAR and SR estimates were generated for 1989, the year when the USGS breccia-pipe evaluations were entered in the URAD data base, and for 1990. The revised values for EAR and SR for 1989 are shown in Table 2. For 1992, the threshold value for the average grade cutoff was removed altogether. This was done in order to reflect more accurately the entire range in grades of the uranium inventory represented by the grade-tonnage curves for each control area. This change resulted in overall iricreases in the estimates for the total EAR and SR cost categories with progressively smaller increases with progressively higher cost category. The change offset the decreases due to increases in economic indexes. Estimates for years prior to 1990 would also be affected by this change; however, the change in the values would not be significant and therefore have not been made.

Estimates of undiscovered resources shown in Table 2 represent the rounded totals of the expected values of the distributions of estimates in million pounds $\mathrm{U}_{3} \mathrm{O}_{8}$ for all areas at the end of 1991 . For 1991 , the mean values for the $\$ 30-, \$ 50-$, and \$100-per pound $\mathrm{U}_{3} \mathrm{O}_{8}$ forward-cost EAR category resources show no change when compared to the values shown for 1990 . The mean values for the $\$ 30-, \$ 50-$, and 
\$100-per pound $\mathrm{U}_{3} \mathrm{O}_{8}$ forward-cost $\mathrm{SR}$ forward-cost category show increases of 8, 5, and 3 percent, respectively.

\subsection{Distribution of EAR and SR by Resource Region}

Estimates of EAR and SR for the United States are reported for resource regions defined by geologic and physiographic characteristics (Figure 1). The mean values of EAR and SR are summarized by principal resource region and forwardcost category in Table 3. In 1989, Colorado Plateau showed a 135 percent increase in the $\$ 50$-per pound $\mathrm{U}_{3} \mathrm{O}_{8}$ EAR category when compared with the 1988 value ${ }^{3}$. This marked increase was due to new discoveries and greatly improved knowledge of the distribution of breccia-pipe deposits in the Grand Canyon region of Arizon. developed in the past 10 years 4 . In 1990, the Colorado Plateau quantity for \$50-per pound $\mathrm{U}_{3} \mathrm{O}_{8} \mathrm{EAR}$ was slightly lower, which resulted from increased values of economic indexes used in the undiscovered-resource cost model for 1990 as compared with 1989. In 1991, the decreases due to increased economic indexes are offset, in most regions and cost categories, by the increases due to the removal of the grade-cutoff threshold value (compare Table 3 with Table A3). The greatest increases are in the Northern Rockies Resource Region where increases for the EAR and $\mathrm{SR} \$ 30$-per pound $\mathrm{U}_{3} \mathrm{O}_{8}$ are 50 percent, the $\mathrm{SR} \$ 50$-per pound $\mathrm{U}_{3} \mathrm{O}_{8}$ is 31 percent, and the SR \$100-per pound $\mathrm{U}_{3} \mathrm{O}_{8}$ is 24 percent. These increases are due to the newly assessed Flodelle Creek area. There are mixed increases ranging from 1 to 12 percent for other regions and a decrease of 3 percent for EAR \$50-per pound $\mathrm{U}_{3} \mathrm{O}_{8}$ in the Wyoming Basins. The total values for EAR are essentially unchanged whereas the total values for SR have increased from 3 to 7 percent in all categories. The distribution of $\$ 50$-per pound $\mathrm{U}_{3} \mathrm{O}_{8}$ EAR in the 7 regions is shown in Figure 3.

\footnotetext{
${ }^{3}$ Energy Information Administration, 1991, Uranium industry annual, 1990: Energy Information Administration, U.S. Department of Energy, DOE/EIA-0478(90), 133 p.

4 W.I. Finch and others, "The 1987 Estimate of Undiscovered Uranium Endowment in SolutionCollapse Breccia-Pipes in the Grand Canyon Region of Northern Arizona and Adjacent Utah, "U.S. Geological Survey Circular 1051 (Washington, C.C.: U.S. Government Printing Office, 1990).
} 


\subsection{Distribution of EAR and SR by Land Status}

The distribution by land status of mean values for \$50-per pound EAR and SR at the end of 1991 is shown in Table 4. Compared with 1990, there is no change in the mean values of EAR. For the SR category, there are slight increases in the mean value for Bureau of Land Management and Forest Service Lands, Indian Lands, State Lands, and Private Fee Lands. 
Table 1. Uranium Endowment by Resource Region at the End of 1991 [Million Pounds $\mathrm{U}_{3} \mathrm{O}_{8}$ ]

\begin{tabular}{|c|c|c|}
\hline Resource Region & $\begin{array}{l}\text { Endowment Associated with } \\
\text { Estimated Additional Resources a }\end{array}$ & $\begin{array}{l}\text { Endowment Associated with } \\
\text { Speculative Resources }\end{array}$ \\
\hline 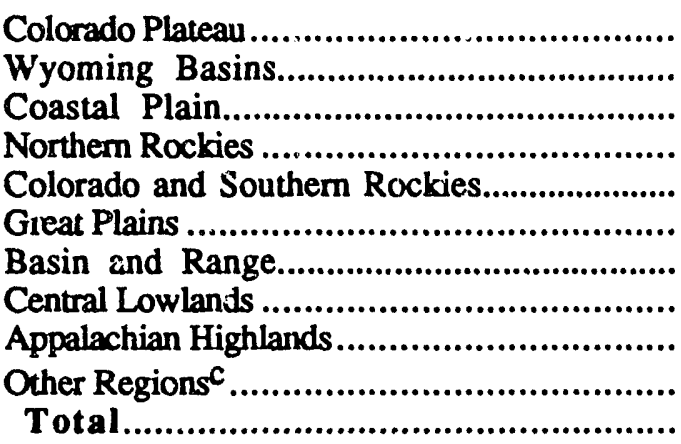 & $\begin{array}{r}3,950 \\
1,990 \\
910 \\
680 \\
320 \\
310 \\
1,420 \\
(b) \\
120 \\
50 \\
9,750\end{array}$ & $\begin{array}{r}2,430 \\
450 \\
410 \\
3,940 \\
360 \\
950 \\
1,080 \\
280 \\
1,140 \\
120 \\
11,160\end{array}$ \\
\hline \multicolumn{3}{|c|}{$\begin{array}{l}\text { Values shown are the mean values for the distributions of estimates for each forward-cost category, rounded to } \\
\text { the nearest } 10 \text { million pounds } U_{3} \mathrm{O}_{8} \text {. } \\
\text { b No uranium endowment in the Estimated Additional Resources category is estimated for this resource region. } \\
\text { Includes endowment associated with Estimated Additional Resources for Pacific Coast region and Alaska and } \\
\text { endowment associated with Speculative Resources for Columbia Plateau, Pacific Coast, and Southem Canadian } \\
\text { Shield regions and Alaska. } \\
\text { Note: Totals may not equal sum of components because of independent rounding. } \\
\text { Sources: U.S. Department of Energy, Grand Junction Project Office, Statistical Data of the Uranium Industry } \\
\text { (January 1983). Estimates based on uranium resources data developed under the DOE National Uranium Resource } \\
\text { Evaluation (NURE) program, using methodology described in An Assessment Report on Uranium in the United } \\
\text { States of America (October 1980), and in U.S. Department of Energy, Uranium Industry Seminar (October 1980) } \\
\text { and under the USGS Uranium Resource Assessment project using in part methodology described in USGS Circular } \\
994 \text { (1987). }\end{array}$} \\
\hline
\end{tabular}


Table 2. Estimated Additional Resources (EAR) and Speculative Resources (SR) at the End of the Year, 1974-1991

[Million Pounds $\mathrm{U}_{3} \mathrm{O}_{8}$ ]

\begin{tabular}{|c|c|c|c|c|c|c|c|c|c|c|}
\hline \multirow{3}{*}{ Year } & \multicolumn{8}{|c|}{ Forward-Cost Category in Nominal Dollars ${ }^{a}$} & & \\
\hline & \multicolumn{2}{|c|}{$\$ 10$ per pound } & \multicolumn{2}{|c|}{$\$ 15$ per pound } & \multicolumn{2}{|c|}{$\$ 30$ per pound } & \multicolumn{2}{|c|}{$\$ 50$ per pound } & \multicolumn{2}{|c|}{$\$ 100$ per pound } \\
\hline & EAR & SR & EAR & $\mathbf{S R}$ & EAR & SR & EAR & SR & EAR & SR \\
\hline 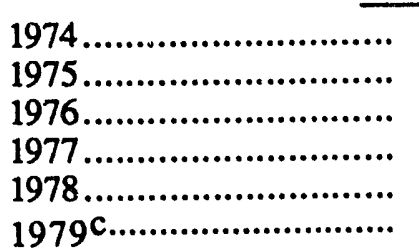 & $\begin{array}{l}900 \\
900 \\
600 \\
\text { (b) } \\
\text { (b) } \\
\text { (b) }\end{array}$ & $\begin{array}{r}1,000 \\
1,100 \\
400 \\
\text { (b) } \\
\text { (b) } \\
\text { (b) }\end{array}$ & $\begin{array}{r}1,400 \\
1,300 \\
1,200 \\
1,100 \\
800 \\
800\end{array}$ & $\begin{array}{r}1,700 \\
1,900 \\
1,400 \\
1,300 \\
600 \\
600\end{array}$ & $\begin{array}{l}2,300 \\
2,100 \\
2,200 \\
2,000 \\
2,000 \\
2,000\end{array}$ & $\begin{array}{l}3,500 \\
3,700 \\
3,200 \\
3,100 \\
2,000 \\
2,000\end{array}$ & $\begin{array}{r}\text { (b) } \\
\text { (b) } \\
2,700 \\
2,800 \\
3,000 \\
3,000\end{array}$ & $\begin{array}{r}\text { (b) } \\
\text { (b) } \\
3,900 \\
4,200 \\
3,400 \\
3,400\end{array}$ & $\begin{array}{l}\text { (b) } \\
\text { (b) } \\
\text { (b) } \\
\text { (b) } \\
\text { (b) }\end{array}$ & $\begin{array}{l}\text { (b) } \\
\text { (b) } \\
\text { (b) } \\
\text { (b) } \\
\text { (b) } \\
\text { (b) }\end{array}$ \\
\hline 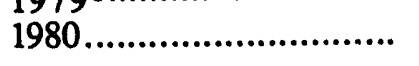 & (b) & (b) & 600 & 300 & 1,800 & 1,300 & 2,900 & 2,200 & 4,200 & 3,400 \\
\hline 1981 & (b) & (b) & (b) & (b) & 1,200 & 900 & 2,200 & 1,800 & 3,500 & 2,900 \\
\hline $1982 \ldots \ldots \ldots \ldots \ldots \ldots \ldots \ldots \ldots \ldots \ldots \ldots$ & (b) & (b) & (b) & (b) & 1,300 & 900 & 2,300 & 1,800 & 3,800 & 3,000 \\
\hline $1983 \ldots \ldots \ldots \ldots \ldots \ldots$ & (b) & (b) & (b) & (b) & 1,300 & 1,000 & 2,400 & 2,000 & 3,800 & 3,200 \\
\hline $1984 \ldots \ldots \ldots \ldots \ldots \ldots \ldots \ldots$ & (b) & (b) & (b) & (b) & 1,300 & 1,000 & 2,300 & 2,000 & 3,700 & 3,200 \\
\hline $1985 \ldots \ldots \ldots$ & (b) & (b) & (b) & (b) & 1,300 & 1,000 & 2,400 & 1,900 & 3,800 & 3,200 \\
\hline 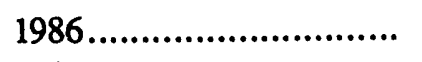 & (b) & (b) & (b) & (b) & 1,300 & 1,000 & 2,400 & 1,900 & 3,800 & 3,200 \\
\hline 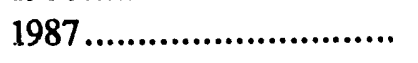 & (b) & (b) & (b) & (b) & 1,300 & 1,000 & 2,300 & 2,000 & 3,700 & 3,200 \\
\hline 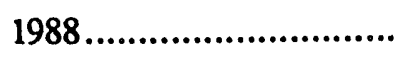 & (b) & (b) & (b) & (b) & 1,300 & 1,000 & 2,300 & 2,000 & 3,800 & 3,200 \\
\hline 1989 & (b) & (b) & (b) & (b) & $\mathrm{R} 2,300$ & $\mathrm{R} 1,400$ & 3,400 & $\mathbf{R} 2,300$ & 5,000 & 3,500 \\
\hline 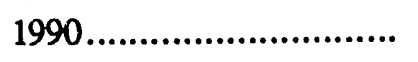 & (b) & (b) & (b) & (d) & 2,200 & 1,300 & 3,400 & 2,200 & 4,900 & 3,500 \\
\hline 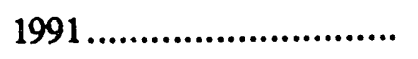 & (b) & (b) & (b) & (d) & 2,200 & 1,400 & 3,400 & 2,300 & 4,900 & 3,600 \\
\hline
\end{tabular}

a Values shown are the mean values for the distributions of estimates for each forward-cost category, rounded to the nearest 100 million pounds $\mathrm{U}_{3} \mathrm{O}_{8}$. Resource values in forward-cost categories are cumulative: that is, the quantity at each level of forward cost includes all resources at the lower cost in that category.

b Not estimated for the indicated forward-cost category.

c No new estimates were released for the end of 1979, since the NURE program was to publish estimates of undiscovered resources by October 1980.

d Resource values were estimated for the $\$ 15$ per pound $\mathrm{U}_{3} \mathrm{O}_{8}$ forward-cost category, but were not included in the table.

$\mathbf{R}=$ Revision.

Sources: 1974-1982-U.S. Department of Energy, Grand Junction Project Office, Statistical Data of the Uranium Industry (January 1983). 1983-1991-Estimates based on uranium resources data developed under the DOE National Uranium Resource Evaluation (NURE) program, 1974-1983, using methodology described in An Assessment Report on Uranium in the United States of America (October 1980), and in U.S. Department of Energy, Uranium Industry Seminar (October 1980) and under the USGS Uranium Resource Assessment project using in part methodology described in USGS Circular 994 (1987). 
Table 3. Estimated Additional Resources (EAR) and Speculative Resources (SR) by Resounce Region at the End of 1991

[Million Pounds $\mathrm{U}_{3} \mathrm{O}_{8}$ ]

Forward-Cost Category in Nominal Dollars ${ }^{a}$

\begin{tabular}{|c|c|c|c|c|c|c|}
\hline \multirow[t]{2}{*}{ Resource Region } & \multicolumn{2}{|c|}{$\$ 30$ per pound } & \multicolumn{2}{|c|}{$\$ 50$ per pound } & \multicolumn{2}{|c|}{$\$ 100$ per pound } \\
\hline & EAR & SR & EAR & SR & EAR & SR \\
\hline 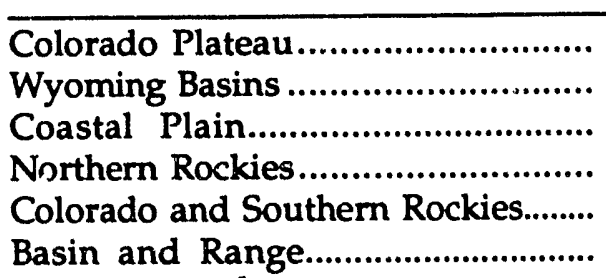 & $\begin{array}{r}1,370 \\
170 \\
380 \\
30 \\
140 \\
60\end{array}$ & $\begin{array}{r}500 \\
90 \\
130 \\
120 \\
90 \\
110\end{array}$ & $\begin{array}{r}1,940 \\
350 \\
500 \\
60 \\
180 \\
170\end{array}$ & $\begin{array}{l}800 \\
170 \\
180 \\
210 \\
140 \\
190\end{array}$ & $\begin{array}{r}2,570 \\
680 \\
610 \\
170 \\
220 \\
410\end{array}$ & $\begin{array}{r}1,240 \\
260 \\
240 \\
310 \\
190 \\
340\end{array}$ \\
\hline 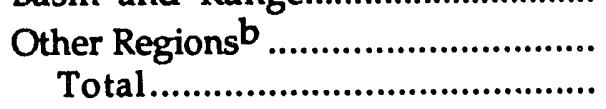 & $\begin{array}{r}110 \\
2,240\end{array}$ & $\begin{array}{r}350 \\
1,400\end{array}$ & $\begin{array}{r}190 \\
3,390\end{array}$ & $\begin{array}{r}640 \\
2,330\end{array}$ & $\begin{array}{r}270 \\
4,920\end{array}$ & $\begin{array}{l}1,020 \\
3,580\end{array}$ \\
\hline
\end{tabular}

a Values shown are the mean values fer the distributions of estimates for each forward-cost category, rounded to the nearest 10 million pounds $\mathrm{U}_{3} \mathrm{O}_{8}$. Resource values in forward-cost categories are cumulative: that is, the quantity at each level of forward cost includes all resources at the lower cost in that category.

b Includes Appalachian Highlands, Great Plains, Pacific Coast and Sierra Nevada, Centrai Lowlands, and Columbia Plateau regions and Alaska.

Note: Totals may not equal sum of components because of independent rounding.

Source: Prepared by staff of the U.S. Geological Survey, U.S. Department of the Interior, based on uranium resources data developed under the DOE National Uranium Resource Evaluation (NURE) program and the USGS Uranium Resource Assessment project, using methodology described in $A n$ Assessment Report on Uranium in the United States of America (October 1980), and in U.S. Department of Energy, Uranium Industry Seminar (October 1980). 
Table 4. Estimated Additional Resources (EAR) and Speculative Resources (SR) in the \$50-per Pound Forward-Cost Category by Land Status at the End of 1991

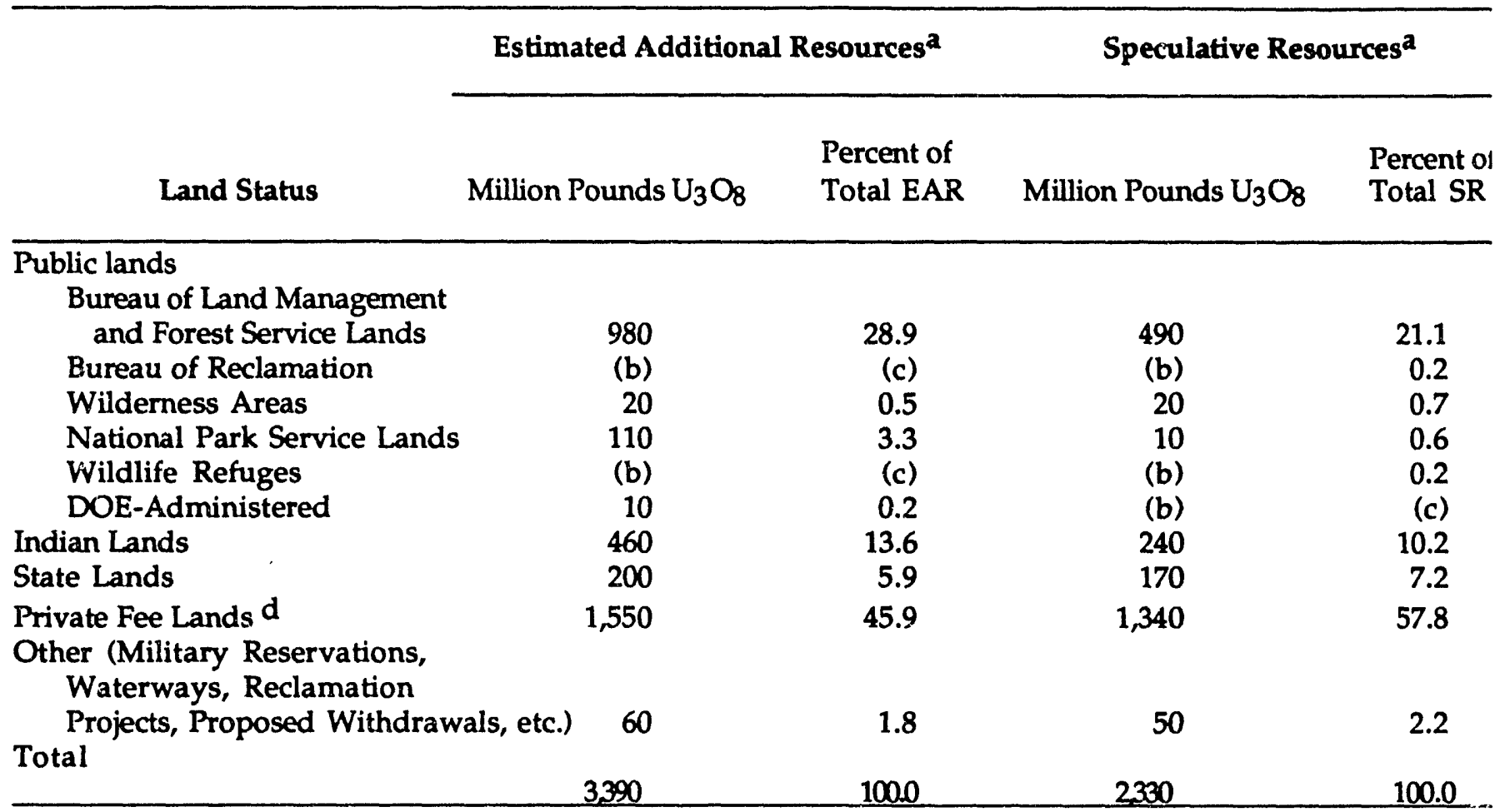

a Values shown are the mean values for the distributions of estimates of EAR and SR, rounded to the nearest 10 million pounds $\mathrm{U}_{3} \mathrm{O}_{8}$.

$b$ Value is less than 5 million pounds $\mathrm{U}_{3} \mathrm{O}_{8}$.

c Value is less than 0.05 percent.

$\mathrm{d}$ Includes railroad lands and patented claims.

Note: Totals may not equal sum of components because of independent rounding.

Source: Prepared by staff of the U.S. Geological Survey, U.S. Department of the Interior, based on uranium resources data developed under the DOE National Uranium Resource Evaluation (NURE) program and the USGS Uranium Resource Assessment project, using methodology described in An Assessment Report oi: Uranium in the United States of America (October 1980), and in U.S. Department of Energy, Uranium irdusty Seminar (October 1980). 


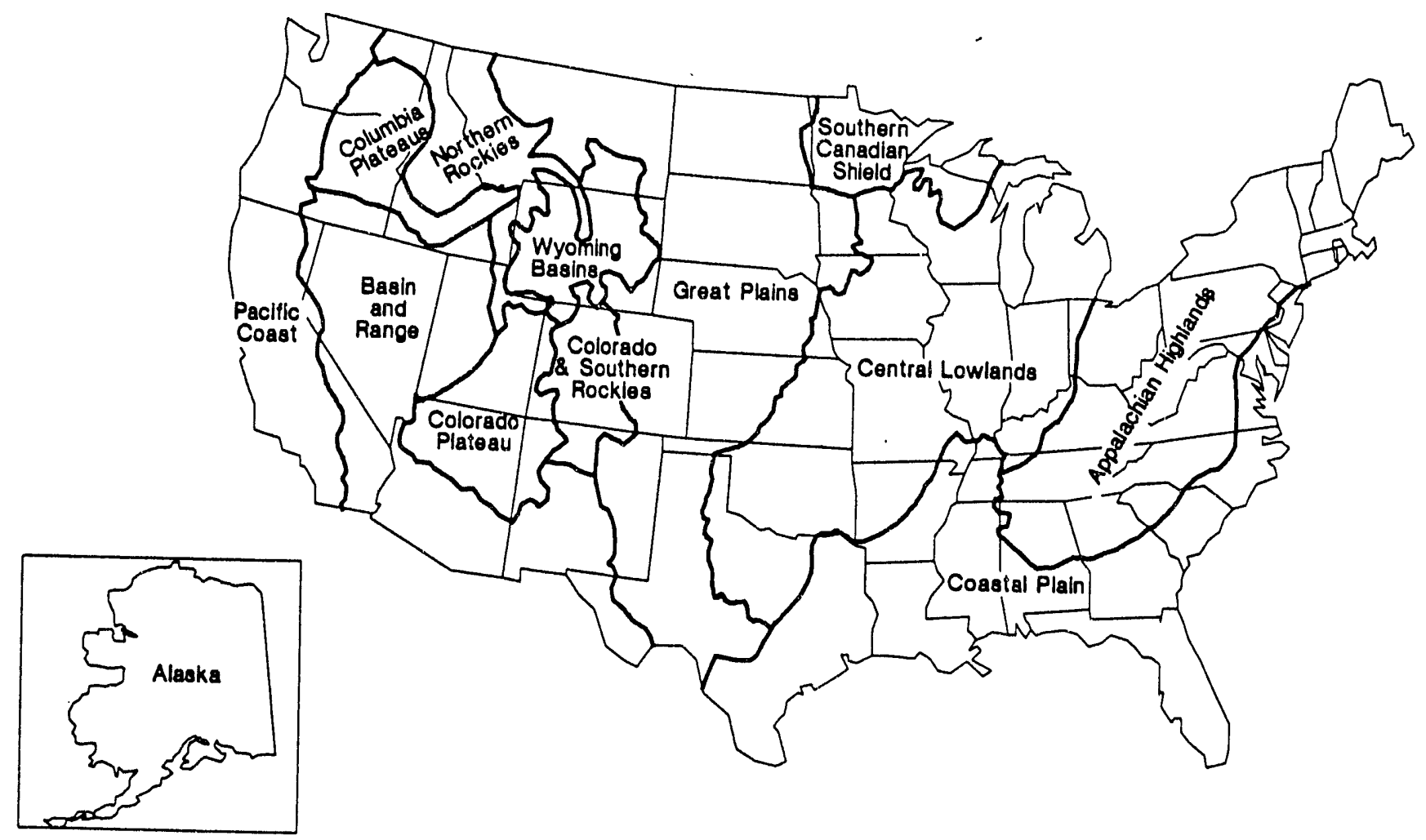

Source: U.S. Department of Energy, An Assessment Report on Uranium in the United States of America, GJO-111(80) (Grand
Junction, Colorado, October 1980).

Figure 1.-Uranium resource regions of the United States. 


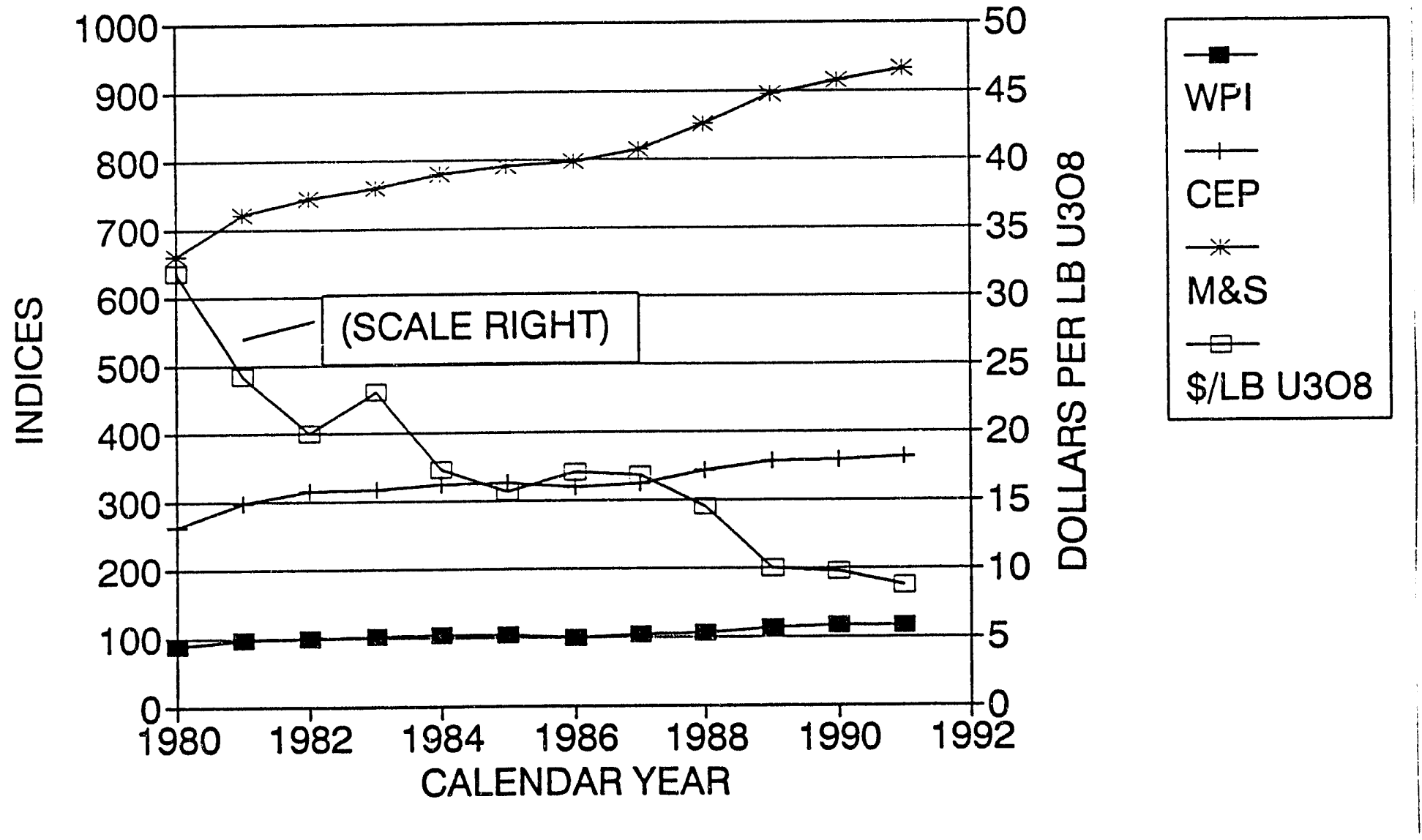

Figure 2. Trends of the economic indexes Wholesale Price Index-Industrial Commodities (WPI), the Marshall and Swift Mining-Milling Equipment Cost Index (MSI), and the Chemical Engineering Plant Cost Index (CEP) and of the average annual $\mathrm{U}_{3} \mathrm{O}_{8}$ spot market prices as determined by the average of NUEXCO monthly exchange prices from 1980-1991. 


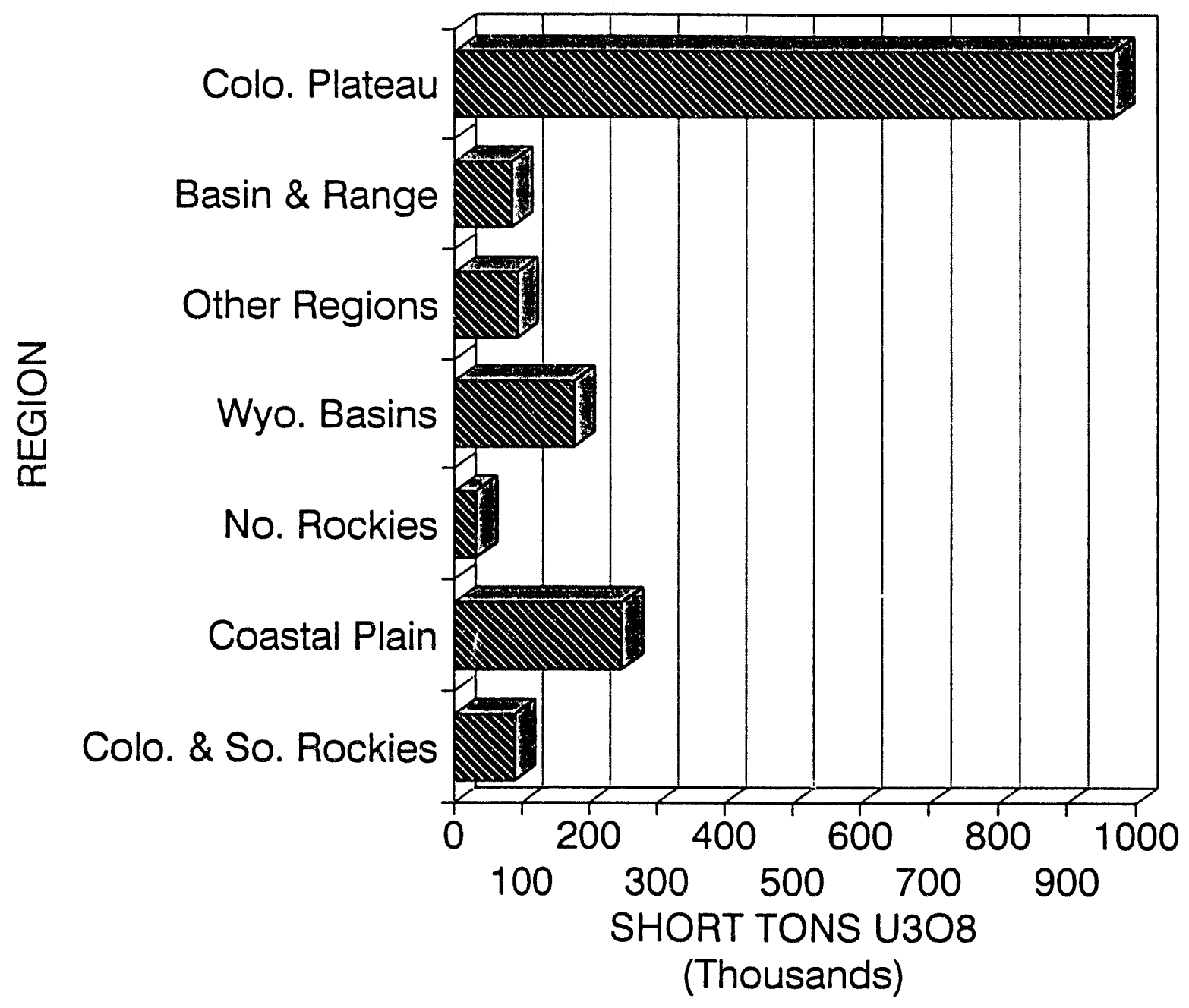

Figure 3.-Distribution of $\$ 50$-pound $\mathrm{U}_{3} \mathrm{O}_{8}$ EAR by region. 


\subsection{ADJUSTMENT TO GRADE CUT-OFF THRESHOLD VALUE}

\subsection{Resource Estimates for Obtained Using the Grade Cut-off Threshold Value of}

\subsection{Percent $\mathrm{U}_{3} \mathrm{O}_{8}$}

In generating the 1991 resource estimates reported in the main body of this report, the grade cut-off threshold value used in the URAD cost model was removed. As explained in the main body of the report, the reason for removing the grade cut-off threshold value was to reflect more accurately the entire range in grades of the uranium inventory represented by the grade-tonnage curves for each control area. This change resulted in overall increases in the estimates for the total EAR and SR cost categories. In this addendum, the resource estimates for 1991 are presented retaining the grade cut-off threshold of 1.00 percent $\mathrm{U}_{3} \mathrm{O}_{8}$ that was applied in generating the resource estimates for 1990. The resource estimates that correspond to retaining the grade cut-off threshold of 1.00 percent $\mathrm{U}_{3} \mathrm{O}_{8}$ are shown in tables 5 through 8. 
Table 5. Uranium Endourment by Resource Region ai the End of 1991

[Million Pounds $\mathrm{U}_{3} \mathrm{O}_{8}$ ]

\begin{tabular}{|c|c|c|}
\hline Resource Region & $\begin{array}{l}\text { Endowment Associated with } \\
\text { Estimated Additional Resources }\end{array}$ & $\begin{array}{l}\text { Endowment Associated wit } \\
\text { Speculative Resources }\end{array}$ \\
\hline 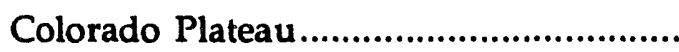 & 3,950 & 2,430 \\
\hline 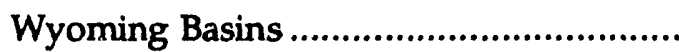 & 1,990 & 450 \\
\hline Coastal Plain. & 910 & 410 \\
\hline Northern Rockies & 680 & 3,940 \\
\hline Colorado and Southern Rockies.................... & 320 & 360 \\
\hline 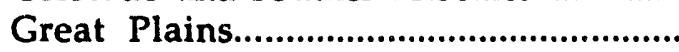 & 310 & 950 \\
\hline 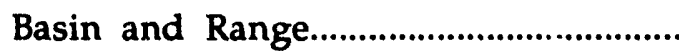 & 1,420 & 1,080 \\
\hline 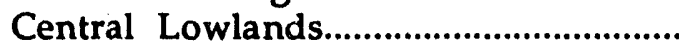 & (b) & 280 \\
\hline 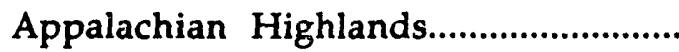 & 120 & 1,140 \\
\hline $\begin{array}{l}\text { Other Regions }{ }^{c} \\
\text { Total }\end{array}$ & $\begin{array}{r}50 \\
9,750\end{array}$ & $\begin{array}{r}120 \\
11,160\end{array}$ \\
\hline
\end{tabular}

a Values shown are the mean values for the distributions of estimates for each forward-cost category, rounded to the nearest 10 million pounds $\mathrm{U}_{3} \mathrm{O}_{8}$.

b No uranium endowment in the Estimated Additional Resources category is estimated for this resource region.

c Includes endowment associated with Estimated Additional Resources for Pacific Coast region and Alaska and endowment associated with Speculative Resources for Columbia Plateau, Pacific Coast, and Southern Canadian Shield regions and Alaska.

Note: Totals may not equal sum of components because of independent rounding.

Sources: U.S. Department of Energy, Grand Junction Project Office, Statistical Data of the Uranium Industry (January 1983). Estimates based on uranium resources data developed under the DOE National Uranium Resource Evaluation (NURE) program, using methodology described in $A n$ Assessment Report on Uranium in the United States of America (October 1980), and in U.S. Department of Energy, Uranium Industry Seminar (October 1980) and under the USGS Uranium Resource Assessment project using in part methodology described in USGS Circular 994 (1987). 
Table 6. Estimated Additional Resources (EAR) and Speculative Resources (SR) at the End of the Year, 1974-1991

[Million Pounds $\mathrm{U}_{3} \mathrm{O}_{8}$ ]

\begin{tabular}{|c|c|c|c|c|c|c|c|c|c|c|}
\hline \multirow{3}{*}{ Year } & \multicolumn{10}{|c|}{ Forward-Cost Category in Nominal Dollars ${ }^{a}$} \\
\hline & \multicolumn{2}{|c|}{$\$ 10$ per pound } & \multicolumn{2}{|c|}{$\$ 15$ per pound } & \multicolumn{2}{|c|}{$\$ 30$ per pound } & \multicolumn{2}{|c|}{$\$ 50$ per pound } & \multicolumn{2}{|c|}{$\$ 100$ per pound } \\
\hline & $\overline{\text { EAR }}$ & $\overline{S R}$ & EAR & SR & EAR & $\overline{S R}$ & EAR & SR & EAR & SR \\
\hline 1974 & .......900 & 1,000 & 1,400 & 1,700 & 2,300 & 3,500 & (b) & (b) & (b) & $\overline{(b)}$ \\
\hline 1975 & .......900 & 1,100 & 1,300 & 1,900 & 2,100 & 3,700 & (b) & (b) & (b) & (b) \\
\hline 1976 & ......600 & 400 & 1,200 & 1,400 & 2,200 & 3,200 & 2,700 & 3,900 & (b) & (b) \\
\hline 1977 & $\ldots . . . .(b)$ & (b) & 1,100 & 1,300 & 2,000 & 3,100 & 2,800 & 4,200 & (b) & (b) \\
\hline 1978 & $\ldots \ldots(b)$ & (b) & 800 & 600 & 2,000 & 2,000 & 3,000 & 3,400 & (b) & (b) \\
\hline $1979 c$ & $\ldots . . .(b)$ & (b) & 800 & 600 & 2,000 & 2,000 & 3,000 & 3,400 & (b) & (b) \\
\hline 1980 & $\ldots \ldots . .(b)$ & (b) & 600 & 300 & 1,800 & 1,300 & 2,900 & 2,200 & 4,200 & 3,400 \\
\hline 1981 & .......(b) & (b) & (b) & (b) & 1,200 & 900 & 2,200 & 1,800 & 3,500 & 2,900 \\
\hline 1982 & .......(b) & (b) & (b) & (b) & 1,300 & 900 & 2,300 & 1,800 & 3,800 & 3,000 \\
\hline 1983 & $\ldots \ldots$ (b) & (b) & (b) & (b) & 1,300 & 1,000 & 2,400 & 2,000 & 3,800 & 3,200 \\
\hline 1984 & $\ldots \ldots$ (b) & (b) & (b) & (b) & 1,300 & 1,000 & 2,300 & 2,000 & 3,700 & 3,200 \\
\hline 1985 & .......(b) & (b) & (b) & (b) & 1,300 & 1,000 & 2,400 & 1,900 & 3,800 & 3,200 \\
\hline 1986 & .......(b) & (b) & (b) & (b) & 1,300 & 1,000 & 2,400 & 1,900 & 3,800 & 3,200 \\
\hline 1987 & .......(b) & (b) & (b) & (b) & 1,300 & 1,000 & 2,300 & 2,000 & 3,700 & 3,200 \\
\hline 1988 & .......(b) & (b) & (b) & (b) & 1,300 & 1,000 & 2,300 & 2,000 & 3,800 & 3,200 \\
\hline 1989 & .......(b) & (b) & (b) & (b) & $\mathrm{R} 2,300$ & $\mathrm{R} 1,400$ & 3,400 & $\mathbf{R} 2,300$ & 5,000 & 3,500 \\
\hline 1990 & .......(b) & (b) & (b) & (d) & 2,200 & 1,300 & 3,400 & 2,200 & 4,900 & 3,500 \\
\hline 1991 & .......(b) & (b) & (b) & (d) & 2,200 & 1,300 & 3,400 & 2,200 & 4,900 & 3,500 \\
\hline
\end{tabular}

a Values shown are the mean values for the distributions of estimates for each forward-cost category, rounded to the nearest 100 million pounds $\mathrm{U}_{3} \mathrm{O}_{8}$. Resource values in forward-cost categories are cumulative: that is, the quantity at each level of forward cost includes all resources at the lower cost in that category.

b Not estimated for the indicated forward-cost category.

c No new estimates were released for the end of 1979, since the NURE program was to publish estimates of undiscovered resources by October 1980.

d Resource values were estimated for the $\$ 15$ per pound $\mathrm{U}_{3} \mathrm{O}_{8}$ forward-cost category, but were not included in the table.

$\mathrm{R}=$ Revision.

Sources: 1974-1982-U.S. Department of Energy, Grand Junction Project Office, Statistical Data of the Uranium Industry (January 1983). 1983-1991-Estimates based on uranium resources data developed under the DOE National Uranium Resource Evaiuation (NURL) program, 1974-1983, using methodology described in An Assessment Report on Uranium in the United States of America (October 1980), and in U.S. Department of Energy Uranium Industry Seminar (October 1980) and under the USGS Uranium Resource Assessment project using in part methodology described in USCS Circular 994 (1987). 
Table 7. Estimated Additional Resources (EAR) and Speculative Resounces (SR) by Resource Region at the End of 1991

[Million Pounds $\mathrm{U}_{3} \mathrm{O}_{8}$ ]

Forward-Cost Category in Nominal Dollars ${ }^{a}$

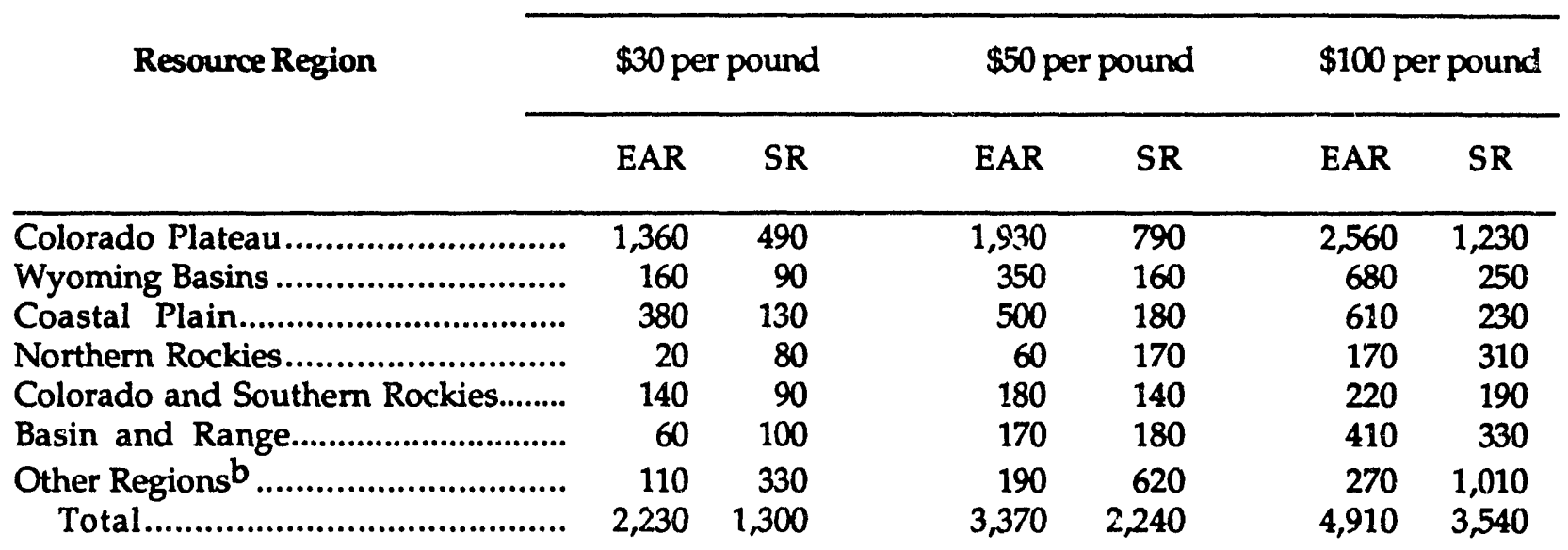

a Values shown are the mean values for the distributions of estimates ror each forward-cost category, rounded to the nearest 10 million pounds $\mathrm{U}_{3} \mathrm{O}_{8}$. Resource values in forward-cost categories are cumulative: that is, the quantity at each level of forward cost includes all resources at the lower cost in that category.

b Includes Appalachian Highlands, Great Plains, Pacific Coast and Sierra Nevada, Central Lowlands, and Columbia Plateau regions and Alaska.

Note: Totals may not equal sum of cornponents because of independent rounding.

Source: Prepared by staff of the U.S. Geological Survey, U.S. Department of the Interior, based on uranium resources data developed under the DOE National Uranium Resource Evaluation (NURE) program and the USGS Uranium Resource Assessment project, using methodology described in An Assessment Report on Uranium in the United States of America (October 1980), and in U.S. Department of Energy, Uranium Industry Seminar (October 1980). 
Table 8. Estimated Additional Resources (EAR) and Speculative Resources (SR) in the S50-per Pound ForwardCost Category by Land Status at the End of 1991

\begin{tabular}{|c|c|c|c|c|}
\hline \multirow[b]{2}{*}{ Land Status } & \multicolumn{2}{|c|}{ Estimated Additional Resources ${ }^{\mathbf{a}}$} & \multicolumn{2}{|c|}{ Speculative Resources ${ }^{a}$} \\
\hline & Million Pounds $\mathrm{U}_{3} \mathrm{O}_{8}$ & $\begin{array}{l}\text { Percent of } \\
\text { Total EAR }\end{array}$ & Million Pounds $\mathrm{U}_{3} \mathrm{O}_{8}$ & $\begin{array}{l}\text { Percent of } \\
\text { Total SR }\end{array}$ \\
\hline \multicolumn{5}{|l|}{ Public lands } \\
\hline \multicolumn{5}{|l|}{ Bureau of Land Management } \\
\hline and Forest Service Lands & 970 & 28.9 & 460 & 20.4 \\
\hline Bureau of Reclamation & (b) & (c) & (b) & 0.2 \\
\hline Wilderness Areas & 20 & 0.5 & 20 & 0.7 \\
\hline National Park Service Lands & 110 & 3.3 & 10 & 0.6 \\
\hline Wildlife Refuges & (b) & (c) & (b) & 0.1 \\
\hline DOE-Administered & 10 & 0.2 & (b) & (c) \\
\hline Indian Lands & 460 & 13.6 & 230 & 10.4 \\
\hline State Lands & 200 & 5.9 & 160 & 7.2 \\
\hline Private Fee Lands $\mathrm{d}$ & 1,550 & 45.9 & 1,300 & 58.2 \\
\hline \multicolumn{5}{|l|}{$\begin{array}{c}\text { Other (Military Reservations, } \\
\text { Waterways, Reclamation }\end{array}$} \\
\hline Projects, Proposed Withdrawa & als, etc.) & 1.8 & 50 & 2.2 \\
\hline Total & 3,370 & 100.0 & 2,240 & 100.0 \\
\hline
\end{tabular}

a Values shown are the mean values for the distributions of estimates of EAR and SR, rounded to the nearest 10 million po'.nds $\mathrm{U}_{3} \mathrm{O}_{8}$.

b Value is less than 5 million pounds $\mathrm{U}_{3} \mathrm{O}_{8}$.

c Value is less than 0.05 percent.

d Includes railroad lands and patented claims.

Note: Totals may not equal sum of components because of independent rounding.

Source: Prepared by staff of the U.S. Geological Survey, U.S. Department of the Interior, based on uranium resources data developed. under the DOE National Uranium Resource Evaluation (NURE) program and the USGS Uranium Resource Assessment project, using methodology described in An Assessment Report on Uranium in the United States of Amerisa (October 1980), and in U.S. Department of Energy, Uranium Industry Seminar (October 1980). 


\subsection{RUNNING THE URAD SYSTEM ON USGS COMPUTERS}

\subsection{Improvements and Additions to the URAD System}

Data retrieval from the URAD system can now be performed using the dBase IV version 1.5 data base management system. Only a single line of code must be removed from each of the previously used $\mathrm{dBXL}$ program files to make them work with dBase IV. The URAD data files do not have to be changed in any way to make the conversion from the $\mathrm{dBXL}$ system. The conversion to $\mathrm{dBase} I V$ was made because this system is more widely used and flexible than $\mathrm{ABXL}$, and is somewhat faster.

The ORNL plotting program SUM27 could not be converted for use on the PC because the code made calls to plotting software not available on the PC. Instead, program JAPREP was modified to produce a table of percentiles of the probability distribution of the uranium resources. This table can be readily imported to the Quattro Pro spread sheet program, and plots of the probability distributions of uranium resources can be made using Quattro graphics routines. A graph showing SR, EAR, and total uranium endowment (Figure 4) was produced by invoking a Quattro Pro macro specially written for that purpose.

Program JAPREP was further modified to produce output files for import to Quattro Pro which can be quickly converted into formatted tables suitable for inclusion in the ELA publication Uranium Industry Annual. Macros have been written to produce tables B2, B3, and B4 of the from JAPREP output files, and table B5 from program RLSREP output (Uranium Industry Annual 1991 ).

Prior to the above changes, the tables had to be created by hand transcription of various lines of data from the output files, a slow and tedious process.

\subsection{Debugging FORTRAN Source Code of URAD Programs}

The FORTRAN source code libraries of the URAD system were recompiled using Microsoft's Version 5.1 FORTRAN compiler to detect any problems in these 
libraries which had hitherto gone undetected. Several "variable type-size" mismatches were found and these errors were corrected. Limited testing of the corrected versions of the URAD programs has not indicated any change in results from those of the uncorrected versions. 


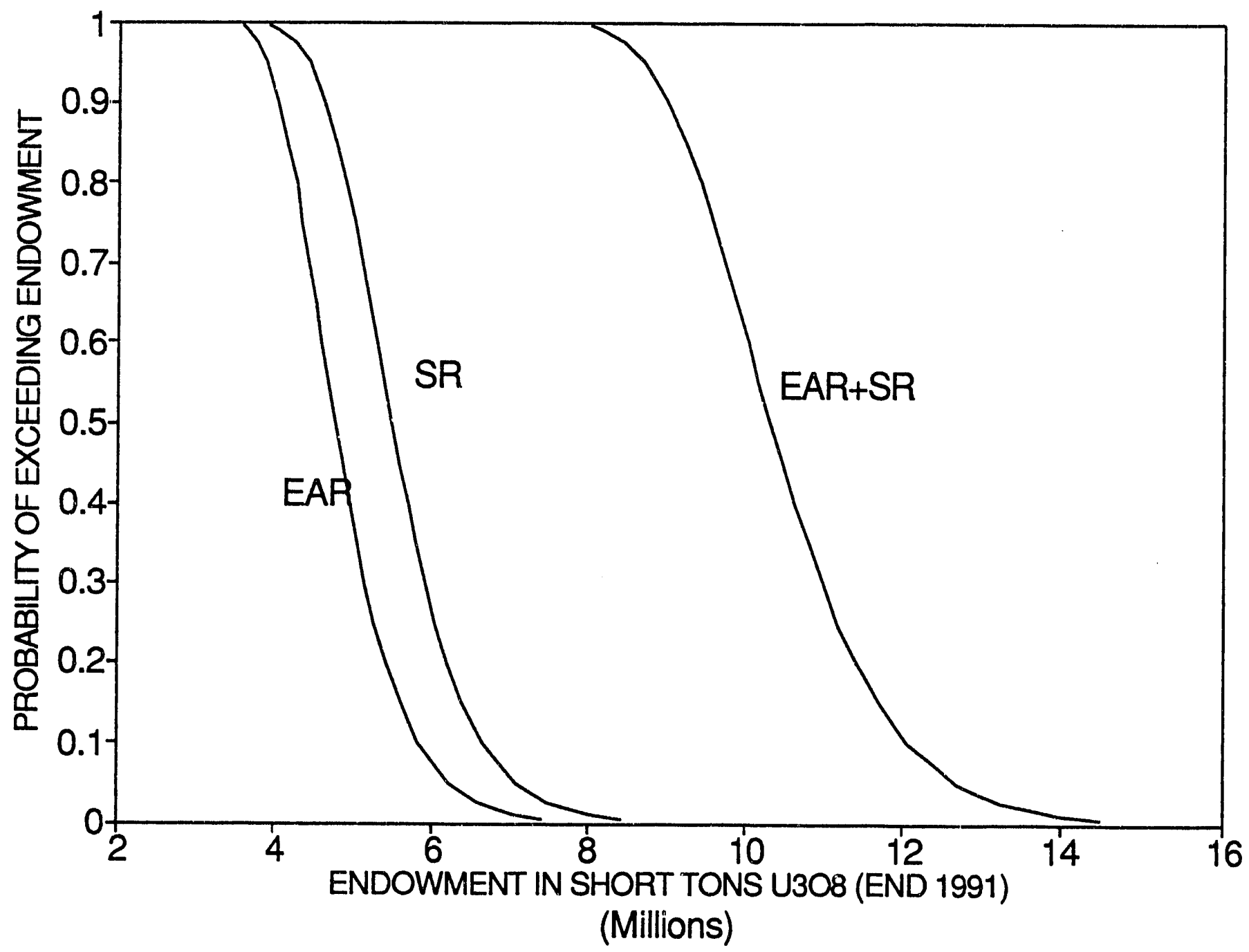

Figure 4.--Probability plot of U.S. potential uranium resources. 


\subsection{RECOMMENDATIONS}

Specific recommendations are made based upon the work that was performed by the USGS under the terms in the current Contract.

\subsection{Proposal for Update of Mining and Milling Cost Models}

Over the decade of the 1980's, the US and world metal mining industry have changed dramatically as a result of the rationalization of industrial capacity, introduction of new technologies, and the general imposition of much stricter measures to protect the environment. The domestic uranium industry is no exception as most US production has come from mines that probably did not exist at the start of the decade. The USGS incorporates new geologic data to update its assessments of uranium endowment. However, the EIA uranium mining and milling cost models, which were developed and estimated in the early 1980's, are no longer appropriate for calculating the forward cost categories for the resource. These models do not characterize the mining technology used at currently operating mines. Specifically, the mining costs for breccia-pipe uranium extraction, new environmental measures for open-pit mining, and in situ solution mining are not adequately represented in the models. Furthermore, any expansion in production will likely require new milling capacity that will incorporate new technology and that will have to meet new environmental regulations.

Initially, any increase in funding would be used to contract for the development of generalized cost models for mining breccia-pipe type ore deposits. If feasible and within the project budget cost, generalized cost models for the associated milling operations will also developed as part of the mining configuration. Mining and milling costs should be expressed as functions of the grade, geologic factors (depth, rock type), and annual capacity as well as factors relating to the degree of environmental regulations imposed. 


\subsection{State Tax Equations}

The USGS agrees with EIA that there is a need to check on current state tax codes, to add new state severance/royalty tax equations, and to modify the existing equations where necessary. It is recommended that this work be undertaken as part of next year's Contract.

\subsection{Automation and Networking}

It is proposed that under next year's Contract, further efforts be made to automate the generation of assessment reports that are submitted to the EIA and to explore the opportunities of establishing a computer network for communication between the USGS and the EIA. 


\subsection{REFERENCES}

Blanchfield, D.M., 1980, Methodology for uranium resource estimates and reliability, in Uranium Industry Seminar Proceedings, October 22-23, 1980, Grand Junction, Colorado: U.S. Department of Energy GJO-108(80), U.S. Geological Survey, Denver, Colorado, p. 59-76.

Chen, G.L., Das, Sujit, and Whitaker, R.A., 1990, Users guide, A computerized database system for uranium resource assessments: Resources and Energy: January 30, 1990, Users guide Uranium: Resource Assessment Database System (URAD-PC Version 1.1), Oak Ridge National Laboratory for U.S. Department of Energy under contract DE-AC05-84OR21400, 16 p.

Das, S., and Lee, R., 1991, A computerized database system for uranium resource assessments: Resources and Energy, v. 13, no. 2, p. 201-215.

Das, S., Ford, C.E., and McCarter, C.T., 1988, The uranium resources assessment data (URAD) system-operations manual: Oak Ridge National Laboratory, Martin Marietta Energy Systems, Inc. for the U.S. Department of Energy, Contract No. DE-AC05-840R21400, 36 p., Appendices A-D.

Energy Information Administration, 1990, Uranium Industry Annual 1989: Energy Information Administration, U.S. Department of Energy DOE/EIA-0478(89), $121 \mathrm{p}$.

Energy Information Administration, 1991, Uranium Industry Annual 1990: Energy Information Administration, U.S. Department of Energy DOE/EIA-0478(90), $133 \mathrm{p}$.

Energy Information Administration, 1992, Uranium Industry Annual 1991: Energy Information Administration, U.S. Department of Energy DOE/EIA-0478(91), $137 \mathrm{p}$.

Finch, W.I., and McCammon, R.B., 1987, Uranium resource assessment by the Geological Survey: Methodology and plan to update the National resource base: U.S. Geological Survey Circular 994, 31 p.

Finch, W.I., Sutphin, H.B., Pierson, C.T., McCammon, R.B., and Wenrich, K.J., 1990, The 1987 estimate of undiscovered uranium endowment in solution-collapse breccia pipes in the Grand Canyon region of northern Arizona and adjacent Utah: U.S. Geological Survey Circular 1051, 19 p.

Ford, C.E., and McLaren, R.A., 1980, Methods for obtaining distributions of uranium occurrence from estimates of geologic features: U.S. Department of Energy Report GJBX-165(80) 121 p. 
McCammon, R.B., Finch, W.I., Grundy, W.D., and Pierson, C.T., 1991, Maintaining the uranium resources data system and assessing the 1990 U.S. uranium potential resources-Final Report, December 31, 1991: Partial fulfillment of contract under interagency agreement DE-AI01-91EI22610, U.S. Department of Energy, Office of Scientific and Technical Information (OSTI), P.O. Box 63, Oak Ridge, Tennessee 37830, $31 \mathrm{p}$.

McCammon, R.B., Finch, W.I., Pierson, C.T., and Bridges, N. J., 1988, The microcomputer program TENDOWG for estimating undiscovered uranium endowment: U.S. Geological Survey Open-File Report 88-653a,-653b, 11 p., 1 diskette.

U.S. Department of Energy, 1980, An assessment report on uranium in the United States of America: U.S. Department of Energy Report GJO 111 (80), U.S. Geological Survey, Denver, Colorado, 150 p., 6 microfiche.

\section{DISCLAIMER}

This report was prepared as an account of work sponsored by an agency of the United States Government. Neither the United States Government nor any agency thereof, nor any of their employees, makes any warranty, express or implied, or assumes any legal liability or responsibility for the accuracy, completeness, or usefulness of any information, apparatus, product, or process disclosed, or represents that its use would not infringe privately owned rights. Reference herein to any specific commercial product, process, or service by trade name, trademark, manufacturer, or otherwise does not necessarily constitute or imply its endorsement, recommendation, or favoring by the United States Government or any agency thereof. The views and opinions of authors expressed herein do not necessarily state or reflect those of the United States Government or any agency thereof. 

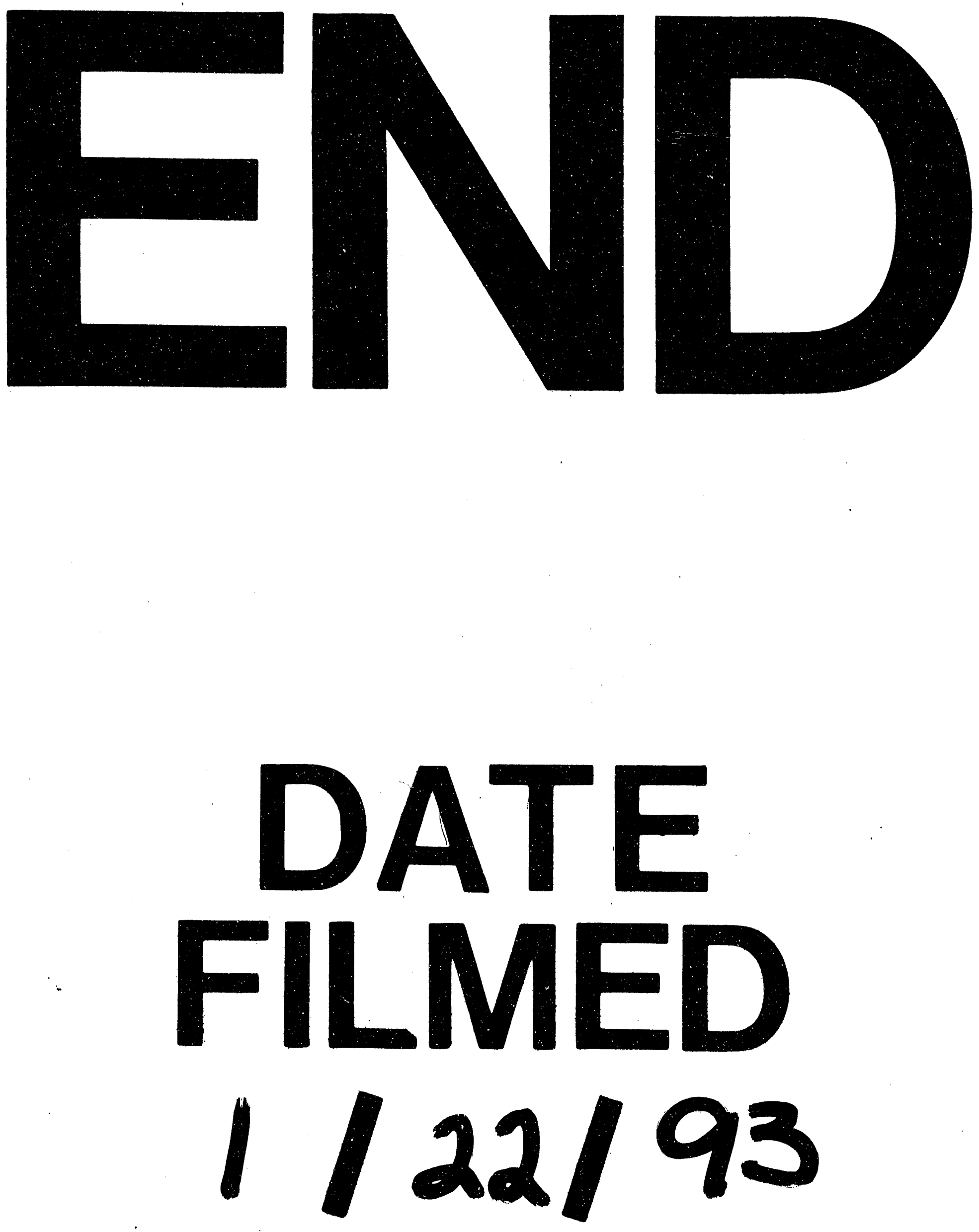
